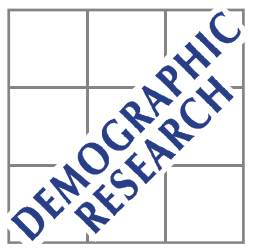

Demographic Research a free, expedited, online journal

of peer-reviewed research and commentary in the population sciences published by the Max Planck Institute for Demographic Research

Konrad-Zuse Str. 1, D-18057 Rostock · GERMANY

www.demographic-research.org

DEMOGRAPHIC RESEARCH

VOLUME 17, ARTICLE 16, PAGES 465-496

PUBLISHED 07 DECEMBER 2007

http://www.demographic-research.org/Volumes/Vol17/16/

DOI: $10.4054 /$ DemRes.2007.17.16

Research Article

Fertility as a process of social exchange

\title{
Patrick Heady
}

(C) 2007 Heady

This open-access work is published under the terms of the Creative Commons Attribution NonCommercial License 2.0 Germany, which permits use, reproduction \& distribution in any medium for non-commercial purposes, provided the original author(s) and source are given credit. See http:// creativecommons.org/licenses/by-nc/2.0/de/ 


\section{Table of Contents}

1 Introduction 466

2 Anthropological theories of gift exchange and their application to 467 kinship

$2.1 \quad$ Gift exchange $\quad 467$

$\begin{array}{lll}2.2 & \text { Young people as gifts } & 468\end{array}$

$2.3 \quad$ Groups as long-term givers and receivers 469

2.4 Authority, solidarity and consent 470

$3 \quad$ Reproductive exchange and fertility 471

$4 \quad$ Case study of the development of ultra-low fertility 474

4.1 Introduction $\quad 474$

4.2 Background and trends 475

4.3 The traditional exchange system 476

4.4 Changing attitudes to parenthood and marriage 478

$\begin{array}{lll}4.5 & \text { Discussion of the case study } & 481\end{array}$

$5 \quad$ Reproductive exchange systems, economic change and fertility in 482

$\begin{array}{ll}\text { Europe as a whole } & \\ 5.1 & \text { Reproductive exchange systems and their economic context }\end{array}$

5.2 Exchange and fertility 485

6 Concluding discussion $\quad 488$

$7 \quad$ Acknowledgments $\quad 490$

$\begin{array}{ll}\text { References } & 491\end{array}$ 


\title{
Fertility as a process of social exchange
}

\author{
Patrick Heady ${ }^{1}$
}

\begin{abstract}
By marrying and raising children, parents participate in a system of gift-exchange in which the gifts in question are human lives, and the parties to the exchange are the kinship groups recognised in the society concerned. Fertility reflects the attitudes of prospective parents to their place in the existing system of reproductive exchange, and the relationships of cooperation and authority which it implies - as well as their confidence in the system's continuing viability. It is shown that this view is compatible with earlier ideas about self-regulating population systems - and that changing economic circumstances are an important source of discrepancy between existing exchange systems and the attitudes and expectations of prospective parents. The discussion is developed with reference to data on European societies, including a casestudy from the Alps, and concludes with an assessment of the relevance of the anthropological theory of gift exchange to contemporary fertility patterns in Europe and beyond.
\end{abstract}

\footnotetext{
${ }^{1}$ Max Planck Institute for Social Anthropology, Halle, Germany.
} 


\section{Introduction}

In this paper I will draw on anthropological theory to offer a view of the connection between economic organization, social relationships and fertility. The approach developed here is based on the idea that more is involved in fertility decisions than concerns about the welfare of the parents and their potential offspring - and that parents have children, in part at least, for the sake of other people. The discussion will focus on the possible bases of an obligation to have children, and how these connect with the strategic moves that can be made to create human and social capital. I will formulate these connections in terms of theories of gift exchange. The idea that exchange processes may be involved in systems of fertility regulation is not itself new, but it is usually presented in the context of specific cultural forms (Fricke 1997) or stages of economic development (Lesthaeghe 1983: 411) - and the content of the exchanges is often conceptualised in economic terms as a matter of intergenerational flows of wealth and practical assistance (Caldwell 1976, 2005). As we shall see, gift exchange in the anthropological sense is distinct from economic exchange - though typically linked to it. I shall argue in this paper that the principles of gift exchange are relevant to fertility levels in all societies, and underline this point by drawing most of the empirical material referred to here from contemporary Europe - an area in which kinship institutions, and associated systems of exchange, are often thought to have been reduced to little more than residual phenomena.

The discussion proceeds in five stages. In section 2 there is a brief review of Mauss's theory of gift exchange, and its application to kinship by Lévi-Strauss and other writers (which I refer to as 'reproductive exchange'). In section 3, I consider the implications of reproductive exchange theory for fertility - and compare it with other theoretical approaches. Section 4 is a case study of the development of ultra-low fertility, based on my own fieldwork in the Italian Alps. Section 5 reviews the evidence for reproductive exchange in European societies, and uses it to develop an interpretation of the recent reversal of the historical fertility gradient between north western Europe and the rest of the continent. Section 6 concludes with some general reflections on the relation between exchange theory and other anthropological approaches. 


\section{Anthropological theories of gift exchange and their application to kinship}

\subsection{Gift exchange}

The anthropological theory of gift exchange was first formulated as such in a celebrated essay by Mauss (1990[1924]). Mauss posits three obligations

1. to give - where there is an existing social relationship;

2. to receive - in the same circumstances; and

3. to reciprocate - when a gift has been given and accepted.

Mauss drew on ethnographic and historical examples of ceremonial gift exchange, including the potlatch (competitive gift exchange) of societies on the northwest coast of north America and (most famously) Malinowski's (1922) ethnography of the circular exchange of kula valuables in an inter-island trading network off eastern New Guinea. It is worth looking a little more closely at the exchange of kula valuables since Malinowski's account contains the initial description of elements that are implicit or explicit in most anthropological accounts of gift exchange. The first of these is that the gifts may or may not have a use value (the kula valuables were simply ornaments), but they must be expensive in terms of the resources and/or effort required to obtain them, and they must matter deeply to the giver as well as to the receiver. It is this kind of gift that Mauss's three rules apply to, and the key point about them is that the appropriate and repeated exchange of gifts creates a relationship within which more immediately practical transactions can take place. (Readers familiar with the recent evolutionary literature will be reminded of the theory of costly signalling (Smith 2003).) In the case of kula trading, the formal process of gift giving created a context which made pragmatic inter-island trading possible.

Three more points are important about the kula and characteristic of many exchange systems in the anthropological literature. The first is that exchange is competitive: not everyone can get to exchange with an influential partner, and the cost of success includes extra effort and expense which not all can afford. The second point is that, despite the individual strategies and competition, the kula is a recognised institution creating a sense of symbolic and practical community over a well-defined geographic area. The third point is a corollary of the other two: namely that each gift is a public performance - and a large part of the subjective reward for each giver is public acknowledgment that he has played his part well. Although the most famous examples of gift exchange in the anthropological literature come from Melanesia, symbolically loaded exchanges are reported from all continents. There is a question, however, of how 
far the theory can be applied to European societies. Mauss himself seemed undecided on the point, and a number of authors have argued that symbolic exchange has been pushed aside by the development of modern capitalism. Others dispute this and Davis (1992:79) has argued that symbolic exchange may be just as important in Europe as anywhere else - but simply less visible to social scientists working close to home than to anthropologists studying non-European societies as outsiders. In this paper I will adopt Davis's point of view.

\subsection{Young people as gifts}

The possible relevance of gift exchange to demography may become a little more apparent when we note that in nearly all known societies the events that demographers study - births (or naming ceremonies), marriages and deaths - are accompanied by gifts and other symbolically loaded transfers of property. However, regarding the theory to be developed in this paper, the crucial advance was made by Lévi-Strauss (1969 [1949]) in his well-known observation that the incest taboo means that women (or, more generally, marriage partners of either sex) are exchanged between kin groups. As LéviStrauss points out, this means that young women (or young people generally) are themselves the supreme gift - mattering hugely to the givers, vital to the very existence of the receiving group and, though Lévi-Strauss didn't stress this, extremely expensive to produce. It follows theoretically, and in fact, that gifts of young women (or young people of either sex) in marriage, and the subsequent reciprocation and repetition of the gifts over future generations, are used by their kin as a way of building social relationships and competing for status - and also define fields of social relationships (geographic or status groups) within which a level of practical cooperation is expected.

For Lévi-Strauss, young marriageable adults provide a means of establishing social ties - but he treats the existence of these young adults as a given, and doesn't discuss the value of parental labor as such. However, while the labor embodied in a child reinforces her value as a gift, it is also present in children who are not given away in marriage. This suggests a second possible exchange, between parents and children, in which the initial parental gift of life and upbringing is returned by the children either as later work for their parents, or by themselves producing offspring who will be the grandchildren of the original parents and in some sense continue their identity. This second possibility highlights the difference between gift exchange and the exchange of goods and services. For the purposes of gift exchange a grandchild can still be a highly valued gift for his or her grandparents even if s/he is not likely to render them any specific services. (The notion of descent as exchange lacks a founding theoretical 
statement as clear as that made for affinal ${ }^{2}$ exchange by Lévi-Strauss's comment about incest and the exchange of women. However, the connection between descent and exchange is already implicit in the work of Malinowski (1929:103-110), and has received further elaboration by Strathern (1988; see also Gell 1999). A number of other writers from Dumont (2006 [1971]) to Allen (2000: 75-89), consider that descent and affinal relationships should be analysed as part of a single overall scheme.)

\subsection{Groups as long-term givers and receivers}

A very important point about these exchanges of parental labour and of marriage partners is that individuals are not usually considered as straightforwardly the property of other individuals, even of their parents. Individual people belong to groups, and the exchanges are considered to take place between these groups. So brides are usually given away, and received, by entities such as families, houses, descent groups, age and marriage classes, and so on. Similarly the exchange of parental labour from one generation to another is not directly returned to the individuals concerned (except in a limited sense in the form of care for the elderly). Instead, in a lineage society an individual repays what he owes to older members of his decent group by producing new members for the group. So when affinal and intergenerational exchange relations bind the givers and receivers into an overall system of local solidarity, the units of which this system are made are not individuals but groups - usually, but not always, descent groups of some kind.

Of course, the kin groups concerned are those which form part of the society's existing kinship system. This is a point that is made manifest in many ways - from the details of marriages and other life cycle rituals (van Gennep 1981 [1909]), through the transfers of property that accompany marriage and the succession of generations (Comaroff 1980; Goody 1976), to the choice of post marital residence (Lévi-Strauss 1984; Murdock 1949), and the specific terms used to refer to and address particular relatives (Morgan 1997 [1870]; Murdock 1949). Lévi-Strauss's own analysis carried this insight further by showing that systems of exchange marriage take specific forms that vary from society to society - and that the rules of marriage exchange serve to preserve the same pattern of relationships through time. This property of selfperpetuation is inherent in the terminology and rules of the "elementary" marriage systems that he analyses in Lévi-Strauss 1969 [1949].

This raises the issue of how widespread is the tendency for the rules of marriage exchange to promote system-preservation as such. Does it extend to 'semi-complex' and 'complex' systems where the choice of marriage partner is not positively prescribed

\footnotetext{
${ }^{2}$ The word "affinal" is an anthropological term referring to relationships established through marriage
} 
in terms of membership of specific existing kinship categories? One sign that the answer to this question might be "yes" is the frequent existence of rules or preferences for group endogamy - sometimes affecting status groups and sometimes village communities - which tend to preserve the structure of the groups concerned over time. These rules suggest a very widespread tendency to conceive of one's own and other people's actions from the viewpoint of the system as a whole - and to value actions that are, so to speak, system-consistent.

\subsection{Authority, solidarity and consent}

The technical part of Levi-Strauss's analysis focuses entirely on marriage systems, though he makes it clear that he believes that marriage exchange plays a central role in maintaining the overall system of social solidarity, and hence that differences in marriage systems are causally related to differences in other aspects of the system of social exchange. There is a great deal of ethnographic evidence from the kula onwards that exchange systems are related both to the extent of solidarity and to the distribution of authority. Reproductive exchange is no exception to this. A sign of the connection between exchange and the commitment to preserving specific systems of social solidarity is the fact that societies often make a sharp distinction between morally loaded exchanges, such as those involved in marriages, and transactions in which direct gain is the main concern. Parry and Bloch (1989) argue that this distinction is motivated by the wish to protect the relationships of power and economic cooperation involved in the long-term reproduction of society from the pressures arising from short-term competitive transactions.

However, it is not enough to talk about wishes in this abstract way. The theme of the first study of the kind to which Parry and Bloch refer was actually the partial dissolution of such a system that occurred when economic change enabled young men to acquire brides directly, without going through the system of lineage organised exchange payments that underpinned the authority of the elders (Bohannan 1955). Systems of reproductive exchange reinforce particular patterns of power and solidarity and are likely to be particularly favoured by those who benefit from them, and resisted by those who do not.

This brings us back to the dual nature of affinal and parental relationships. They are perceived as symbolic ties that constitute and connect groups in a system of social exchange, but they are also actual activities by specific individuals who nearly always have a good deal of influence on the decisions involved: whether to have another child, whether to get married, whether to organise a marriage for one's child, or to support or hinder the child's own marriage plans. In making their own decisions, and evaluating 
the actions of others, individuals will be influenced by a number of system-consistent desires. The systems would not work at all if individual people did not share a commitment to the basic values and perceptions underlying all exchange systems: specifically that gifts of life (in parenting and marriage) set the scene for a wider set of social relationships; that some relationships and some gifts (even of human lives) are better than others; that gifts of life should be repaid; and that they should form part of a stable system of exchange relationships that can be seen to reproduce itself through time. I take these perceptions and attitudes to be universal.

But the kinds of groups involved in exchange, and the particular ways they are networked into larger systems, are not universal and they have specific implications for authority and cooperation - about which there is scope for overt and hidden dissent within any society.

When individuals dissent, they may choose to exercise their exchange options (of parenting and marriage) in different ways. Or they may choose to withdraw, partly or totally, from the system - by not marrying or marrying late, or by not having (so many) children. This is one reason why the exchange view of kinship has important implications for demography.

\section{Reproductive exchange and fertility}

In fact, the treatment of marriage and parenting as gifts of life has a number of implications for fertility. The first of these is that (in normal circumstances) it sets a lower limit below which fertility would not be expected to fall. This is because the overall requirement to return gifts - including gifts of human life - means that there will be pressure to raise at least as many children to adulthood as was done by previous generations. In effect, this is a homeostatic mechanism that will operate to keep population up to a certain level.

There has been a good deal of discussion of homeostatic mechanisms in historical demography - and in European societies there is some very convincing quantitative data showing how a "nuptiality check" appears to have operated as a homeostatic mechanism adjusting population to economic possibilities in pre-industrial England (Wrigley 2003) and over much of the Alps (Netting 1981; Viazzo 1989). Nuptiality checks seem to have been a European speciality, but several authors have argued using softer data that functionally equivalent checks have operated in most or all societies (Douglas 1966; Lesthaeghe 1980). However, the concern of these authors has mostly been to identify homeostatic mechanisms that keep fertility down. Can these mechanisms have anything to do with a mechanism that operates in the opposite direction, to keep fertility $u p$ ? 
I would argue that they can, since the previous discussion has shown that reproductive exchange operates as part of a system whose overall tendency is selfreplication. Replicating the relationships of people to resources is as much part of this as replicating the relationships of people with each other. So one would expect such a system to include requirements to combine the replication of population with the replication of wealth. In fact, the competition for status means that gift exchange has a certain expansive tendency, since individuals and groups can enhance their status by passing on more than they received - whether in material terms or in terms of human lives. This can be thought of as a ratchet effect, in which the tendency will be at least to reproduce the population numbers and wealth per capita of previous generations but, where medical or economic progress permit, to increase either population, or per capita wealth, or both. This would then set a new standard which subsequent generations would try to reproduce or exceed. At any given time, the need to reproduce the level of per capita wealth would set an upper homeostatic limit to the expansion of population, and vice versa.

This is not incompatible with Becker's account of the economic motives for parenthood, which include both the balance of costs and benefits for the parents themselves, and the economic welfare of their children and their children's descendents. He claims that potential parents aim to maximise their 'dynastic' utility - by which he means a combination of the number of descendents and their average levels of economic consumption, discounted over time (Becker 1993:155-178). He argues that in modern economies, where there are high returns to education, and continuation in education imposes substantial costs on the parents, this function will be optimised at a lower fertility level than in earlier economies where the returns to investment in human capital were lower.

However, our account would modify Becker's analysis in two ways. The first is that this maximisation is constrained between the homeostatic limits. The second is that, because exchanges of life create moral obligations with practical effects, it may make sense in some kinship systems to see children as assets whose disposal in marriage will create social capital for the parents. In such systems, any free play left by the homeostatic limits could be used to produce either additional children or additional wealth. However, in a system in which parents did not control their children's marriages, the incentive to produce additional children would be weaker, and hence the relative attraction of investments in physical or monetary wealth would be greater.

Caldwell's $(1976,2005)$ analysis of net intergenerational wealth flows takes account of the immediate and delayed costs and benefits that accrue to parents in their direct interactions with their children, and also of potential political benefits from future marriage alliances. So the last two paragraphs show that reproductive exchange theory is also compatible with Caldwell's analysis, provided that the effects of 
intergenerational wealth flows are restricted to fertility choices that remain within the homeostatic limits. Caldwell himself also believes that the impact of intergenerational wealth flows is subject to some kind of limits. Although he doesn't define these very precisely, he says that the effects of selfishly rational parental choice are limited by "social, psychological and physiological" factors which ensure that fertility neither falls so low, nor rises so high, as it would if parental economic rationality were its only determinant (Caldwell 1976: 355). Reproductive exchange theory makes it possible to be more definite about this. As noted above, the distance between the upper and lower homeostatic bounds depends on the rate of progress of productive and medical technology. Where this progress is particularly rapid - for instance in societies which are assimilating advanced technologies developed elsewhere - the range of fertility rates that are compatible with the principles of reproductive exchange will be particularly wide. It is in these societies that the direction and size of intergenerational wealth flows would be expected to have most impact on fertility.

Up to this point I have implicitly assumed that the local system of reproductive exchange remains in place, and shown that its effect would be to set homeostatic limits, of varying widths, to the impact of economic incentives. However, reproductive exchange theory also suggests a quite different way in which economic choices may influence fertility. As we noted at the end of Section 2, there is one potential exception to the principle that treating marriage and parenthood as gift exchanges must maintain fertility. This arises because the gifts of life also express and maintain existing systems of cooperation and authority. If exogenous economic developments provide new possibilities of cooperative relationships and authority roles, they simultaneously call into question the existing pattern of reproductive exchange. As people start to take advantage of the new possibilities, and therefore disengage from previous ties of cooperation and authority, they will wish to use the symbolic power of marriage and parenthood to reinforce their new practical relationships. But this may not be easy because, as we have seen, personal strategies of reproductive exchange acquire their meaning and motivating force as parts of a stable, self-reciprocating system - and there is nothing to guarantee that an integrated new system of practical and reproductive exchange will quickly take the place of the old, and no longer sustainable, version. Unable or unwilling to understand their parenthood as a contribution to the old system, but lacking any alternative symbolic framework to give it a larger purpose, potential parents would respond by cutting back their fertility.

Since this may seem both abstract and counter-intuitive, it is worth noting that the scenario just outlined is actually quite similar to that described by the theory of the "second demographic transition" (SDT) (Lesthaeghe 1983³ ${ }^{3}$ Lesthaeghe and Neidert 2006). This is grounded in a wider tradition of sociological modernisation theory which

${ }^{3}$ This 1983 article presents an early version of the theory, before it received its name. 
proposes that modern economies reward individual initiative, while growing prosperity provides people with the opportunity to focus on higher order goals of self-realisation. There is very strong evidence from comparative survey data that this leads to the development of more individualistic value orientations (Inglehart and Welzel 2005). The SDT theorists take the argument one step further and equate this with a rejection of social obligations as such - including the obligation to form traditional marriage ties and the physical business of reproduction. So SDT theory, like reproductive exchange theory, would predict that the breakdown of traditional patterns of economic cooperation would lead to a fall in fertility.

Nevertheless, there are two crucial differences. First: where the SDT theorists associate falls in fertility with a one-way process of increasing self-determination, I associate them with the transition from one system of cooperative relationships to another. And second: where the SDT theorists think in terms of a contrast between selfregulation and the fulfilment of obligations, I have been arguing that some obligations to return the gift of life, to perpetuate a system of relationships one believes in, and to encourage others to do the same - are in fact inclinations. From this point of view, there is no reason to suppose that an increase in values of self-determination (which seems to be very well attested) should lead to a long-term rejection of parenthood. Unlike the SDT theorists, who are inclined to think that European fertility levels will remain permanently below replacement level (Lesthaeghe and Willems 1999), I would predict that - after a more or less prolonged search for new ways of combining reproductive exchange with the increased economic and social emphasis on self-determination - a new system of practical cooperation and reproductive exchange will emerge, which permits a return to replacement fertility.

After these preliminaries it is now time to turn to the case study.

\section{Case study of the development of ultra-low fertility}

\subsection{Introduction}

The area covered by this case study consists of a number of villages in a valley in Carnia - an area of the eastern Italian Alps, where I carried out fieldwork between 1989 and 1991. The thought that fertility might somehow relate to patterns of social relationships arose from that experience. The birth rate was extremely low, the ratio of children to women of child-bearing age being about 1 - only half the number needed for the natural reproduction of the population. In contrast, the proportion of elderly people in the population was high, due to migration from the valley during recent decades, which had particularly affected the age-groups who would, if they had stayed, have 
been aged between 40 and 60 . People often lamented to me that deaths were far more frequent than births.

What struck me, however, was that these complaints formed part of a general litany which included the physical deterioration (as local people saw it) of the landscape as a result of the advance of the woods over land that had previously been kept clear for use as hayfields and meadows. It also included a lament that the tenor of social life had changed. People, so I was told, had become selfish, and no longer lent each other a hand. Life was also less fun now. Though people used to be much less well-off, there had been far more allegria - joyful togetherness - in the old days. The people I spoke to never specified a causal link between fertility and the other economic and social changes, but the fact that they wove them together in their narratives of decline suggested that they were somehow connected - and implicitly posed the question of what the connection might be.

The purpose of this section is to investigate how well the reproductive exchange model, and other approaches, fit this Carnian case. The available data includes quantitative information on fertility and on spatial marriage patterns, as well as quantitative and qualitative data on changing patterns of economic life. ${ }^{4}$ My proposed research topic was "local identity and ritual" and I made a particular study of certain rituals and associated symbolic themes. I will also draw on the impressions I gathered from informal conversations about the declining birth rate, and the factors that influenced the desired number of children. On the other hand I do not have systematic interview data on family formation strategies, or about the economic situation of specific families. Thus I do not have the kind of data that are generally used for testing economic theories. In that sense, it could be argued that this case study is biased in favor of non-economic interpretations. However, I will do my best to relate the available data to economic explanations directly involving flows of goods and services, as well as to the social exchange model developed in this paper. I will also look at the implications of the data for SDT theory

\subsection{Background and trends}

For several centuries the Carnian economy had been based on a combination of smallscale agriculture and livestock raising, forestry and seasonal emigration. Almost all village families were involved in agriculture to some degree. Although people mainly worked their own land on their own account, the agricultural economy was dependent on cooperative work by village families - in keeping the paths to the upper meadows and pastures clear, in clearing snow in winter, in running collectively owned dairies, as

\footnotetext{
${ }^{4}$ The quantitative data are summarised here. Details are given in (Heady 1999).
} 
well as - in some villages - collectively owned woods and pastures. In all this, the cooperative unit was the village community.

As in most alpine communities, fertility in earlier centuries was at the relatively low levels typical of northwest Europe, though much higher of course than in European societies today (Breschi et al. 1999). Most marriages took place between people born in the same multi-village commune and, in the upper villages, a substantial proportion of marriages were between co-villagers.

After the second world war the traditional economy based on agriculture and seasonal emigration went into a decline which, though gradual at first, reached a kind of tipping point about 1970, when the cooperative dairies were closed, people stopped maintaining the paths to the upper pastures, and seasonal emigration came to an end. The decline of the traditional economy did not mean that the local people themselves became poorer. In the decades after the second world war about 40 percent of the population left permanently, but the remainder saw their incomes rise substantially, roughly in line with the increase of earnings that took place in Italy as a whole. Factory and office work played an important role, though many men have continued to work outdoors as lumberjacks and construction workers. On the other hand, employment opportunities for women remained very limited.

The typical length of schooling, which had been very short until the early 1960s, increased rapidly after that. Transport also improved rapidly with the spread of motorcycle and then car ownership, and improvement in the quality of the roads.

At the same time the geographical range of the marriage network started to increase. The proportion marrying partners from the same commune declined and the attitude to marrying partners from the same village changed dramatically. Formerly the socially approved option, same-village marriage came to be regarded by young people as unacceptably close. In the village which I studied most intensely, same-village marriages were frequent until about the time the dairy closed, and then stopped almost completely.

Through all this the birth rate declined steadily to reach the exceptionally low level that applied in the 1980s.

\subsection{The traditional exchange system}

It is now time to consider the traditional social and symbolic framework within which local people made their decisions about marriage and parenthood. Carnian village communities are composed not just of people but of houses, which are both physical and social entities. As buildings they are large, often containing accommodation for more than one nuclear-family unit. But cjasa, the word for "house" in the local speech, 
also means "family". Each village house has a name, often that of an ancestor of the present inhabitants, which can also be used to refer to the members of the patrilineal extended family who live in it. Houses are felt to embody the self-sacrificing work of previous generations (including the in-marrying wives). Self-sacrificing work on behalf of their children is the basis of the rhetorical claims made by older people for authority within the family. The implicit exchange relationship was particularly stressed in the case of sons: until recently, houses were inherited exclusively by sons because they, unlike daughters, were felt to carry on the family line. If a family only had daughters then one of them might marry an outsider, who came to live in her parental home. But this arrangement was seen as extremely humiliating and the in-marrying husband was said to have married like a cuckoo. This was because home ownership, and the correct relationship to previous ancestor-owners, conveyed the authority over other cjasa members which was part of the senior male role.

A correct relationship to houses was a precondition for socially acceptable marriage and fertility. Births outside marriage were and still are rare. However, when they did occur, the custom early in the twentieth century was that the official family name of the child would be chosen by the local registrar. The practice was to assign them names referring to plants - thus indicating that the birth was metaphorically out of doors, excluded from the morally approved world of family houses. It is possible to take this analysis one stage further, and trace a set of ideas that link houses, social competition and physical fertility. Envy was believed to have the potential to directly harm the envied person, by means of such mechanisms as the evil eye. Mothers and children were thought to be particularly subject to dangerous envy from other women. Houses offered protection against this danger, because their walls blocked visual communication. In this way they made the good fortune of those inside the house less provocative to potentially envious outsiders, and also blocked the transmission of dangerous ill wishes by the evil eye. Given these conventions and beliefs, proper housing could be seen as a moral and physical requirement of reproduction.

Although these beliefs seem to be fading, the importance of the physical cjasa as a sign of the family's position in the community is a constant of local culture - and the possession of decent accommodation is still, as it would have been in the past, important for a family's status. Nowadays this accommodation sometimes consists of a couple's own house, and that would always have been a particularly high-status option for young people starting out on married life. But even nowadays it is just as common for a couple to occupy part of a larger house, usually shared with the husband's relatives. The crucial point is that fitting in another reproductive couple would always have meant either accepting more cramped conditions, with their implications for status as well as convenience - or the trouble and expense of new building. And this would 
have provided a brake on the formation of new marriages, and hence on the expansion of the local population.

Turning now to the community as a whole: there is a strong feeling that the people of each village should ideally be united; this is accompanied by a strong sense of rivalry between neighbouring villages; and there was until recently an ideal of village endogamy. Within the village community the model of marriage was one in which the particular families connected changed from generation to generation - so that marriage links tied each lineage to the community as a whole, rather than to a narrower set of exchange partners. This structure corresponded to the local pattern of economic exchange - in as much as the main ties of practical cooperation were also at village level, and many of them required cooperative action by the village as a whole.

This self-reproducing system of kinship and economic cooperation was not just an observer's model, but one which local people were conscious of and deliberately promoted. I remember talking to friends about a village in which the young people were believed to spend a lot of time in each other's company. They remarked that this augured well for the future of that village. This sense of continuity as an explicit value, and the role of young people in promoting it, is embodied in an annual ritual which I have described elsewhere (Heady 1999, 2003). This ritual, known as the cidulas (i.e. disks - because its central episode involved the throwing of burning disks from a hillside above the village) set up an opposition between young adults on the one hand and householders on the other. It represented courtship as taking place between partners from the same village, but asserted that the process was under the control of the young people themselves, not of their elders. However this opposition between the generations was presented within a wider framework of reciprocal exchange, in which the new couples resulting from the courtship would continue the life of the village as a whole.

This ritual was seen as the most important of three annual events which involved the idea of village unity. The other two were sops, a ritual in which every household gave a small present to all of the village children, and rogatsion, in which the community as a whole circled the village fields. All these rituals express a conception of the village as a continuing reproductive and agricultural unit. The sops, and still more the cidulas, go beyond this to express in imagery the principles of reproductive exchange on which the system was founded.

\subsection{Changing attitudes to parenthood and marriage}

My direct conversations about reasons underlying desired family sizes were mostly with middle-aged and younger people. I was aware from other conversations, and from data that I collected on living arrangements, that the duty to care for one's parents in old 
age is generally accepted, and I often saw adolescent and adult children helping their middle-aged and elderly parents with the much reduced agricultural activities that many families still undertake. So it would not be unreasonable if parents were to take account of future help from their children when planning their families.

Everyone was aware that both the cost in time and money of raising children, and the amount of help that parents could expect in return, had changed radically in recent decades. As well as the longer school attendance - now typically well above the legal minimum - parents in 1990 provided their children with a higher material living standard and spent a good deal of time ferrying them between various recreational activities. Children were much less strictly disciplined than they had been before, and the continuing authority of parents over their adult children, which had been a feature of life earlier in the century, was now a thing of the past.

Parents clearly were behaving partly in the way that Becker would predict: providing the support necessary for their children to acquire the education needed for success in the modern economy. But was this the whole reason for the decline in fertility? The way people talked about the choice of family size did not suggest that they were consciously calculating the different levels of benefit (for themselves and their children) that could be obtained from different combinations of family size and education level. Instead they talked of needing to meet the obligations of modern parenthood - in terms of support during education and of general well-being. If these conversations were taken at face value, parents would seem to have been balancing their desire for children against the effort and cost that would be involved in giving those children a socially acceptable life style.

However, there was something about these conversations that didn't quite fit. If costs had risen, incomes too were now much higher; and although mothers complained about the amount of time and energy required to look after children in the modern style, they were not in fact very short of time - since paid employment for women had not increased to match the decline in the amount of time committed to agricultural activities. In other contexts, women complained of having too little to do. If the expense and difficulty of meeting social standards of respectable parenthood were really the only factor restraining parents' enthusiasm for having children, one would expect them to use all the time and resources they could spare. The fact, that they did not do so, suggests that their enthusiasm for parenthood was already low, and that they experienced the work of parenting more as a matter of drudgery than as a fulfilment.

This basic lack of enthusiasm for parenthood as such has more in common with the self-centred attitudes that advocates of SDT theory would expect to accompany the increased prosperity that Carnians have experienced in recent decades. But here too the facts don't quite fit. If parenthood was being cut back on in order to make way for the pursuit of self-fulfilment, one would have expected young and middle aged adults to be 
actively engaged in new forms of self-fulfilment. However, as just indicated, there was little sign of this kind of engagement.

The idea of a simultaneous diffusion of new economic opportunities and a different model of parenthood, implicitly raised a few paragraphs back, is in fact rather misleading. The new norms of parent-child relations did not exist before the diffusion of the economic changes in the second half of the twentieth century. They developed during the process of economic change, and were as new elsewhere in Italy as they were in Carnia. The normative changes are therefore better analysed as the product of social processes which arose in situ as a result of the new economic opportunities. One way of interpreting what happened would be to say that parents initially behaved as rational dynastic strategists, by giving their children the education that they believed would optimize their future earning possibilities - but then found that they had to adapt their parenting style to one that would maintain good relations with educated children who would not, as adults, be economically dependent on the family estate.

The second step, like the first, was rational. But it was not made willingly. In 1990 elderly people and people in later middle age openly expressed their anger at the independent minded and uncooperative behaviour of young people - which they attributed to the new found economic prosperity and the fact that young people no longer depended on the help of their elders and neighbours for their economic subsistence. Younger people, on the whole, were respectful in their comments on their elders, while nevertheless indicating a certain detachment from the attitudes and values of the older generation.

Elderly people were also perplexed by the change that had taken place in marriage patterns. As we have seen, the decline of the old agricultural economy was accompanied by a geographical widening of the choice of marriage partners, meaning that marriages no longer reinforced ties within the village community but were now being used to build social and symbolic connections over a wider social field. One manifestation of this change was the fate of the cidulas ritual. In several villages it was toned down, and in some it was temporarily abandoned because the young people (who took the active roles in the ceremony) felt that it was out-of-line with modern life, and rather embarrassing. However they soon started again, as a result of pressure from the older members of the community. This festival of youth and courtship was important to them, even a generation or more after they themselves had passed through that phase of life - showing clearly the emotional satisfaction they derived from a ritual that represented the idea that their children's marriages would continue the pattern of affinal exchanges in which they themselves had taken part. 


\subsection{Discussion of the case study}

In order to explain the basic lack of enthusiasm for parenthood that prevailed around 1990, it may be helpful to summarise the changes that had occurred during the previous 30 years or so. Over this period village life had changed fundamentally. In 1960 the symbolic mechanisms that set the upper and lower limits to a homeostatic fertility system were both in place. What is more, the patterns of residence and collective celebrations of agriculture, parenthood and affinity - the central elements of the system of reproductive exchange - expressed relationships of intra-lineage authority, and interlineage cooperation within the village, which broadly corresponded to the way the social and economic system actually worked. In 1990 the patterns of residence and the symbolism of household and community, though slightly modified, were still substantially in place. However, the actual economic relationships, as well as the actual patterns of marriage and of intra-household authority, were quite different.

In the former situation a man who married and had children could expect approval because he was carrying forward the identities of his cjasa and his village. A woman who married and had children would receive approval for helping to reproduce the cjasa and village of her husband. If both partners were from the same village, they would also receive approval for perpetuating the ties that united village families. They would have welcomed this approval in an uncomplicated way, since it was coming from the kinship group and community with which they expected to cooperate closely over their whole lives, and with which their personal hopes and ambitions were therefore involved. This consciousness of the approval of the people who mattered to them must have provided young adults with an incentive for marriage and parenthood, or at least a positive emotional basis from which to face the difficulties involved. As such, it must have favoured fertility.

In the new situation this was no longer the case. The symbolism still suggested that marriage and parenthood would perpetuate the cjasa and village, and so potential parents could expect some approval from the older members of both institutions. The problem was that, since the connections that mattered to younger adults now lay largely outside the cjasa and the village, they no longer cared so much - and so the approval of parents and fellow villagers provided less of an incentive for fertility. Indeed, if anything, young adults wanted to loosen connections with their village communities, and their own strong preference for exogamous marriages was in part an expression of this. The hostility of the older generation towards the changed attitudes of the young must also have reinforced the tendency of the latter to distance themselves psychologically from community ties.

So public approval for perpetuating the old institutions of kinship and village solidarity had lost its value as an incentive towards marriage and parenthood. The deeper problem was that nothing equivalent had taken its place. The very persistence of 
the symbolism of sops and cidulas suggests a nostalgia for the idea of a selfreproducing community - and simultaneously demonstrates that local people had not yet succeeded in creating an alternative system of reproductive exchange that would be compatible with the looser and more dispersed ties on which their practical lives were now based.

Thus an explanatory strategy that combines rational economic choice with attention to the implications for inter-personal relationships and the symbolism of reproductive exchange seems to me to provide a persuasive explanation for the demographic changes that occurred in Carnia between 1960 and 1990. It is not the only possible explanation, since the decline in fertility could also be seen as a direct response to the changed balance of current costs and long-term benefits involved in child-rearing, on the part of parents who were investing rationally in future family-based care for their old age. While the explanation suggested here is less parsimonious it does have the advantage of accounting for a wider range of ethnographic data. Further comparisons between the explanatory power of reproductive exchange and other theories are given in the next section.

\section{Reproductive exchange systems, economic change and fertility in Europe as a whole}

\subsection{Reproductive exchange systems and their economic context}

Though Lévi-Strauss himself intended his basic argument to be universal, many anthropologists would doubt the applicability of reproductive exchange theory to modern Europe - arguing that in contemporary and recent European societies households and married couples should be seen as autonomous units rather than as parts of a wider kinship system (Brettell 1991; Goody 1983). In making a case for extending the application of reproductive exchange theory beyond the Carnian example, I shall be making two different kinds of claim. The first claim - for which I will argue in the next few paragraphs - is that local communities with reproductive exchange systems and norms of practical cooperation very like those of Carnia, and broadly similar to those described by numerous ethnographic studies of non-European societies, were characteristic of many areas of rural Europe until very recently indeed. The second kind of claim - which I will develop after that - is that the principles of reproductive exchange continue to influence fertility even in societies in which affinal ties are not closely aligned with local geographic communities. As a preliminary to this argument, the next few paragraphs will also point to evidence that there are some parts of Europe 
in which descent groups and endogamous cooperative local communities have not been socially important for several centuries.

The aspect of reproductive exchange theory whose applicability to Europe has probably been most widely recognised is the idea of a duty to have children in order to continue one's family of origin. Le Bras has argued (1997: 32) that "self perpetuation was the central concern of the traditional European family", and analyzed the differing fertility rates in contemporary Europe as consequences of the tensions that arise during the decay of traditional family models. However, there was a major difference in traditional family systems between northwestern Europe, where the predominant custom before the demographic transition was for new couples to form distinct households, and the rest of the continent, where they would generally join the household of the parents of one or other spouse (Hajnal 1983). Further research has inevitably complicated the simple distinction drawn by Hajnal - in particular by showing that neo-local residence was also the predominant pattern in some parts of southern Europe. However, in an article which reviewed the historical research to date and combined it with contemporary statistical data, Reher (1998) has reaffirmed the validity of the original macro-regional distinction, and shown that a similar north-south distinction still exists between what he calls strong and weak families - as measured in terms of residence patterns and other indicators of contact and cooperation between close relatives. In this connection, he and Micheli (2000) have pointed out that the nuclear family households of Mediterranean Europe are much more tightly integrated into networks of close kin than are those of northwest Europe. Heady (2005) has pointed out that these continuing geographic distinctions broadly coincide with longstanding differences in the emphasis placed on marriage and descent ties in kinship terminologies. Mitterauer (2003) traces the difference in household patterns back to the organisation of feudal society in the middle ages, and argues that the northwest European pattern was connected with the development of market relationships and the need for labour mobility.

Although no European societies conform to the extreme forms of restricted exchange-marriage discussed by Lévi-Strauss, such as the direct exchange of women between descent groups, there are examples of marriage patterns that involve reciprocity within limited groups of related families (Delille1988; Segalen 1991: 88123). Roughly speaking the idea is that family A gives a daughter in marriage to another family in the group (say family B), but receives a bride from a different family $\mathrm{C}$ which is also in the group. In each generation the particular families involved differ, but exchanges remain concentrated within the same set. This set might be defined purely in kinship terms or, as in the Carnian case, it might coincide with a village community. In the latter situation the normative association with generalized social solidarity is particularly clear. In Italy campanilismo - village patriotism and rivalry 
with other villages - is or used to be a prominent value system (albeit one that is often viewed critically by those involved). There is also a well-known saying mogli e buoi di paesi tuoi ("wives and oxen of your own villages") implying that one ought to marry someone from the same village. So, at the level of mental models at least, the emphasized community of moral solidarity coincides with the field of approved affinal ties.

Italy is not alone in this. In detailed studies of Greek communities Loizos (1975: 94-102) and Just (2000) have shown how the practice of endogamous marriage is seen as the foundation of the village's sense of moral community. Heady (2003) points to rituals celebrating endogamous marriage in cooperative village communities across southern Europe from Portugal to Romania. Layton (2003) also notes the correlation between dense networks of affinal ties and cooperative village enterprise. However, the evidence applies to southern and eastern Europe only. Such communities do not appear to have operated much in north western Europe. This point is consistent with the historical traditions of greater spatial mobility and weaker intergenerational ties in that part of the continent, which were a feature of the early forms of capitalist development discussed by Mitterauer.

These reproductive institutions have been undergoing change for some time. As the economic and social conditions that prevailed in Carnia before 1970 were fairly widespread in the village communities of southern Europe in the mid-twentieth century, it is possible that similar development paths were followed in a number of regions. Indeed Solinas and Grilli (2002) report a similar geographic expansion of marriage networks in central Italy. It is also likely that the consequences of migration from the countryside into the cities and suburbs during the second half of the twentieth century would have disrupted existing exchange and cooperative relationships, and widened the social range of marriage networks, at least as much as the changes taking place in the countryside itself.

Changes are also taking place in the composition and stability of reproductive households. In many parts of Europe, but particularly strongly in the north and west, there are signs of much more flexible arrangements developing, with easier partner change, and a tendency to opt out of, or postpone, the wedding celebrations that ritually assign the new couple their place in the system of reproductive exchange. Residence in the new informal households is associated both with economic changes and with the value shifts that accompany modernisation: it is associated with high levels of labour market participation by women (Le Bras 1997), and with values that stress individual self-determination (Surkyn and Lesthaeghe 2004). Cohabitation appears to provide young women with the opportunity of pursuing their education and establishing themselves in a career before committing themselves to motherhood, and is also associated with a more equal allocation of domestic roles than is the case in married 
couples (de Singly and Ciccheli 2003:338). Consistently with this, there is evidence from American research that the stress caused by unequal division of domestic tasks within married couples is greatest for women who participate actively in the labour market and least for women with a "traditional" view of gender roles (Piña and Bengtson 1993).

Several writers have suggested that the increased instability of reproductive couples, together with the continuing rise in longevity, may be leading to an increased role for grand-parents in the process of child-rearing - along with a general strengthening of intergenerational ties - both in Europe and north America (Bengtson 2001; Segalen 2003). However, some caution is in order here. While both of the authors just mentioned cite evidence of the current strength of intergenerational ties, quantitative research on this theme is relatively new - and the data does not yet have enough time depth to show whether the strength of intergenerational relationships is actually increasing (Bengtson 2001:13). Another interpretation, which would fit better with the reproductive exchange hypothesis ${ }^{5}$, is that there have always been supportive relationships between successive reproductive generations - even if these have been stronger in regions where successive generations live with, or close to, each other than in areas where this is not the case.

\subsection{Exchange and fertility}

Summarising this material it seems possible to glimpse the outline of three broad systems of reproductive exchange in contemporary Europe:

1. a traditional southern and eastern system in which localised descent groups (often but not always identified with houses) form local communities whose solidarity is reinforced by frequent marriage ties; the gift relationships are between generations within the descent groups, and between descent groups within the community.

2. a traditional north western system in which married couples form - with the authorisation of church, state, and relatives - and bring up children who leave home to form their own married couples under the same conditions; each couple thus gives its children to the community at large, and receives partners for them from the community at large; the gift

\footnotetext{
${ }^{5}$ This is partly because reproductive exchange implies relations of solidarity, and couples in successive generations are linked to some extent by reproductive exchange, even in systems with neo-local residence. A further reason for scepticism about increasing intergenerational solidarity is the argument developed in the case study, and in this section, that recent economic trends favour looser intergenerational ties.
} 
relationships are therefore both between successive generations of married couples and between each couple and the community at large; the community that is thus tied together is much wider than a local village, and might be conceived of by those involved in various ways - related perhaps to social class, religion or nationality.

3. an emergent system in which the reproductive units are freely formed egalitarian couples - who reject the need for anyone else - whether church, state, or kin - to authorise their relationship; because the system is new it is not entirely clear how intergenerational links will form, but in principle exchanges between different generations of couples, and between the couple and the community at large, could be very similar to those under system 2 - the difference being a new level of independence for younger parents.

As young people everywhere in Europe are now faced with similar demands and opportunities from the modern economy - and system 3 expresses values that are strongly associated with economic modernity - it is unsurprising that it is making some gains in all parts of Europe. However, since the jump from system 2 to system 3 is smaller than that from system 1 to system 3 (or even from system 1 to system 2) it is equally unsurprising that system 3 is growing faster in north western countries than elsewhere in Europe. The result, however, is that the tension between the demands of the modern economy and the demands of the prevailing systems of reproductive exchange is highest in the system 1 countries in southern and eastern Europe, a good deal less in system 2 countries, and lowest of all in those north western countries where system 3 has in effect already become a legitimate alternative to system 2 .

This situation offers us a chance to compare the demographic implications of reproductive exchange theory with the predictions of SDT theory. The SDT view is that the spread of the individualistic values embodied in what I have called system 3 will lead to permanently lower fertility - and so fertility should be lowest where these values are most widespread, and highest in the strong family context of system $1-$ i.e. lowest in the northwest and highest in the south and east. The reproductive exchange view, developed in section 3, and illustrated by the Carnian case study, is that fertility will fall when the economy leads young people to develop economic relationships and value commitments which are at odds with those supported by the symbolism of the prevailing system of reproductive gift exchange. On this view fertility should be lowest where the discrepancy is greatest - i.e. lowest in the south and east and highest in the northwest. Currently the statistical data favour the reproductive exchange view as fertility is now highest in northwest Europe, being negatively correlated with the strength of family ties and positively correlated with the frequency of informal unions 
(Dalla Zuanna 2001). Dalla Zuanna's results, which are based on national figures, are reinforced by Micheli's (2000) finding that in France, Spain and Italy, fertility at the end of the $20^{\text {th }}$ century was lowest in those regions which, like Carnia, were historically characterised by three-generation households.

The statistical data also provide valuable checks of alternative explanations based on direct economic incentives. The possibility, floated at the end of section 4 , that the decline in Carnian birth rates might be a consequence of rational investment in familybased care for one's old age, is not confirmed by the comparative statistical data, since the countries which now have the highest fertility have the weakest intergenerational ties. However, an incentive-based argument within the reproductive exchange framework could help to explain the fact that, before the demographic transition, fertility in northwest Europe was lower than in the rest of the continent (Coale and Treadway 1986). It is clear that the prospects of using parenthood to build social capital would have been less favourable in system 2 societies with high geographic mobility and weak connections between the generations, than in system 1 societies where recognised descent groups persisted over generations in the same place and regularly renewed marriage alliances with each other. The incentive to invest in financial and material assets, rather than in children, would therefore have been highest in the northwest. ${ }^{6}$

So, on the basis of the statistical evidence, an explanatory strategy that combines reproductive exchange with economic rationality performs better than either the SDT hypothesis or explanations based on economic rationality alone.

A key point in favour of the importance of reproductive exchange is the evidence that low fertility is associated, not with economic modernity as such, but with the degree of tension that exists between economic modernity (including the opportunities it offers to women) and existing family forms. However, it is also possible to attribute low fertility to this tension - as Le Bras (1997), Micheli (2000) and, in a way, Dalla Zuanna (2001) do - without invoking the principles of reproductive exchange. So it is reasonable to ask what we gain by bringing reproductive exchange into the picture. The answer is that it provides a theoretically based explanation of why the tension between economic modernity and pre-existing family forms leads to reduced fertility - and that this explanation is backed by ethnographic data.

However, it should also be pointed out that a good deal more ethnographic evidence would be needed to properly substantiate the reproductive exchange view. It

\footnotetext{
${ }^{6}$ It is surprising, at first sight, that Carnia, with its cooperative economy and lineage-based cjasas, finds itself classed with northwestern societies in this respect (Breschi et al 1999) - but there is a possible explanation that would be consistent with section 3's discussion about the circumstances in which investment in physical wealth would be preferred. This is that the choice of marriage partners was traditionally in the hands of the young people themselves - thus making it difficult for parents to use their children's marriages as a basis of personal social capital, and so removing the motive for high fertility.
} 
would be particularly important to have ethnographic data concerning the ideological and ritual aspects of reproductive exchange and the messages they express about the physical reproduction of the next generation, and about the reproduction of the values and relationships that underlie cooperation and constitute the sense of community. While studies of southern and east European communities would provide valuable direct checks of this paper's case study, the need for ethnographic data is greatest in north western Europe, where the central challenge would be to see whether comparable, but distinct, analyses of the symbolism of reproductive exchange could be made for the nuclear-family-based system that was characteristic of northwest Europe, and for the more flexible system that now seems to be emerging.

\section{Concluding discussion}

At the start of this paper I claimed that parents have children "in part at least, for the sake of other people". Another way of putting it would be ... "partly in order to perpetuate a system of relationships". As the argument developed, I made various predictions about what would happen if an underlying commitment to reproductive exchange was combined with rational economic choice in other respects. Though the evidence assembled here is certainly not conclusive, all of it points in the right direction - and seems to show that this theoretical combination of two kinds of exchange motivation is a serious competitor for both SDT and purely economic approaches.

The theory set out in sections 2 and 3 of this paper is not meant to be specific to Europe. Indeed, if interactions between the principles of reproductive gift exchange and patterns of economic cooperation can be shown to influence fertility in Europe - where kinship ties are often supposed to be weaker than elsewhere - the theory has a good chance of being valid everywhere. This is not to say that specific conclusions drawn for European societies could automatically be extended to other places, but rather that applying this approach, in the specific circumstances of the society concerned, would explain (or at least help to explain) the changing local patterns of fertility. In that sense, this paper represents an attempt to produce a general theory that can take account of the richness of specific detail produced by studies in the tradition of anthropological microdemography. (For the methodological views underlying this aspiration see Heady 2007.)

However, the anthropological demography literature is not short of theoretical statements (see the papers in Greenhalgh 1995, and Kertzer and Fricke 1997), some of which - such as Fricke's (1997) work on reciprocity and Bledsoe's statement (1995:152) that "[c]hildren and their wellbeing become cultural symbols which adults use to shape their own relations with each other" - are very close to arguments 
advanced here. So what does the present approach add to the existing formulations concerning strategies, domestic power relationships, political and economic forces, and culture? I should say at once that it does not aim to replace all these statements, but I think it does two important things.

Firstly, as the European examples have shown, it provides a unified framework for analysing the causal paths connecting different social and economic factors to fertility outcomes. Secondly, it provides a theory (or rather the barest outline of a theory) of individual motivation that makes it possible to understand how the decisions of autonomous individuals could nevertheless give rise to cultural systems of fertility regulation, and how these systems might eventually adapt to economic change. Such an account is needed because, without it, there is no way of connecting cultural explanations of fertility with explanations based on individual strategies. If it is accepted that the desire for continuity and balanced exchange, at personal and system levels, is an innate (but not always overwhelming) psychological motive, which is capable of motivating adherence to cultural systems that offer a way of satisfying it, then the ontological gap between socio-cultural and personal-strategic explanations is closed.

A few years ago, an argument of this kind would have run into trouble from two quarters: firstly from cultural constructionists suspicious of anything that looked like an appeal to universal human nature; and secondly from evolutionists who would query how such a socio-centric kind of motivation could possibly have evolved. However, given the growing anthropological interest in cognition (Enfield and Levinson 2006), and the recognition by contemporary evolutionists that far more cooperation takes place than can currently be explained by arguments based on either tit-for-tat reciprocity or direct forms of kinship altruism (Henrich et al 2003), the psychological implications of the argument advanced here might now receive a more sympathetic hearing.

Of course the argument itself raises further questions about the cognitive processes that underlie both the recognition of new (and existing) kinship units and the identification of the wider field of relationships involved in the process of selfperpetuating exchange. However, since these questions must also be answered eventually by any theory of reproductive exchange (regardless of whether it specifically focuses on fertility) - and since the broad outlines of gift exchange theory, and its application to gifts of human life, have survived and developed over more than eighty years of empirical investigation and theoretical controversy - it is likely that valid cognitive explanations can be found. If the empirical demands of demography stimulate this search, then the quantitative requirements of demographic analysis may turn out to have unexpectedly close connections to fundamental developments in anthropological theory . 


\section{Acknowledgments}

I should like to thank my fellow participants at the EAPS Workshop on the Anthropological Demography of Europe (MPI Rostock 2005), and at an earlier workshop at the London School of Economics, for their comments on previous versions of this paper. I am also very grateful to John Simons for a stimulating conversation about the demographic implications of social and religious commitment, and for suggested reading; and to Siegfried Gruber for introducing me to data from the World Values Survey. Most of all I would like to thank the reviewers appointed by Demographic Research whose supportive, but very challenging, comments forced me to clarify and extend the arguments presented here. 


\section{References}

Allen N 2000 Categories and classifications: Maussian reflections on the social. Oxford: Berghahn.

Becker G 1993 A treatise on the family (enlarged edition). Cambridge Mass.: Harvard University Press

Bengston V 2001 The Burgess Award Lecture: Beyond the nuclear family: the increasing importance of multigenerational bonds. Journal of Marriage and the Family 63 (1) 1-16.

Bohannan P 1955 Some principles of exchange and investment among the Tiv. American Anthropologist 57: 60-70.

Breschi M, Gonano G, Lorenzini C 1999 Il sistema demografico alpino. La popolazione della Carnia, 1775-1881. In M Breschi (ed) Vivere in Friuli, saggi di demografia storica, pp 153-192. Udine: Forum.

Brettell C 1991 Property, kinship and gender: a Mediterranean perspective. In D.Kertzer, R.Saller (eds) The family in Italy from antiquity to the present, pp 340-353. New Haven and London: Yale University Press.

Caldwell J 1976 Toward a restatement of demographic transition theory. Population and Development Review 2(3/4): 321-366.

Caldwell J 2005 On net intergenerational wealth flows: an update. Population and Development Review 31(4): 721-740

Coale A, Treadway R 1986 A summary of the changing distribution of overall fertility, marital fertility and the proportion married in the provinces of Europe. In A.Coale, S.Watkins (eds) The decline of fertility in Europe pp31-79. Princeton NJ: Princeton University Press.

Comaroff J (ed) 1980 The meaning of marriage payments. London and New York: Academic Press

Dalla Zuanna G 2001 The banquet of Aeolus: a familistic interpretation of Italy's lowest low fertility. Demographic Research 4 (5) 133-162. www.demographicresearch.org/Volumes/Vol4/5/

Davis J, 1992 Exchange. Buckingham: Open University Press

Delille G 1998 Famiglia e proprietà nel regno di Napoli,XV-XIX secolo. Turin: Einaudi. 
de Singly F, Cicchelli V 2003 Contemporary families: social reproduction and personal fulfilment. In D.Kertzer, M.Barbagli (eds) History of the European family, Volume 3: Family life in the twentieth century pp 311-349. New Haven: Yale University Press.

Douglas M 1966 Population control in primitive groups. British Journal of Sociology 17 (3) 263-273.

Dumont L 2006 [1971] Introduction to two theories of social anthropology: descent and marriage alliance (edited by Robert Parkin). Oxford: Berghahn.

Enfield N, Levinson S (eds) 2006 Roots of human sociality: culture, cognition and interaction. Oxford: Berg.

Fricke 1997 Culture theory and demographic process: towards a thicker demography. In D.Kertzer, T.Fricke (eds) Anthropological demography: towards a new synthesis, pp248-277. Chicago: University of Chicago Press.

Gell A 1999 Strathernograms. In A.Gell The art of anthropology, essays and diagrams (edited by Eric Hirsch), pp 29-75. London: Athlone.

Goody J 1976 Production and reproduction: a comparative study of the domestic domain. Cambridge: CUP.

Goody J 1983 The development of marriage and the family in Europe. Cambridge: CUP.

Greenhalgh S (ed) 1995 Situating fertility: anthropology and demographic enquiry. Cambridge: CUP.

Hajnal J 1983 Two kinds of pre-industrial household formation system. In R Wall, J Robin, P Laslett (eds) Family forms in historic Europe. Cambridge: CUP.

Heady P 1999 The hard people: rivalry, sympathy and social structure in an alpine valley. Amsterdam: Harwood Academic.

Heady P 2003 Conscripts and Christians: representing kinship and affinity in the Carnian Alps. Journal of the Royal Anthropological Institute 9: 77-95

Heady P 2005 Nuclear families and cognatic descent: reflections on two characterisations of European kinship. In P Skalnik (ed) Anthropology of Europe, teaching and research pp 67-76. Prague Studies in Social Anthropology 3. Prague: Set Out. 
Heady P 2007 What can anthropological methods contribute to demography - and how? Demographic Research vol. 16, article 18, pp555-558. http://demographicresearch.org/Volumes/Vol16/18/

Henrich J et al. 2003 Group report: the cultural and genetic evolution of human cooperation. In P.Hammerstein (ed) Genetic and cultural evolution of cooperation, pp 445-468. Cambridge, Mass.: MIT Press.

Inglehart R, Welzel C 2005 Modernisation, cultural change and democracy: the human development sequence. Cambridge: CUP

Just R 2000 A Greek island cosmos. Oxford: James Currey

Kertzer D, Fricke T (eds) 1997 Anthropological demography: towards a new synthesis. Chicago: University of Chicago Press.

Layton R. 2003 What creates village democracy in Europe: a comparative study. In H Grandits and P Heady (eds) Distinct Inheritances: property, family and community in a changing Europe pp 97-114. Münster:LIT.

Le Bras H 1997 Fertility: the condition of self-perpetuation. Differing trends in Europe. In M Gullestad, M Segalen (eds) Family and kinship in Europe pp14-32. London: Pinter.

Lesthaeghe R 1980 On the social control of human reproduction. Population and Development Review 6 (4): 527-548

Lesthaeghe R 1983 A century of demographic and cultural change in western Europe: an exploration of underlying dimensions. Population and development Review 9(3): 411-435.

Lesthaeghe R, Neidert L 2006 The second demographic transition in the United States: exception or text-book example? Population and Development Review, 32(4): 669-698.

Lesthaeghe R, Willems P 1999 Is low fertility a temporary phenomenon in the European Union? Population and Development Review 25(2): 211-228.

Lévi-Strauss C 1969 [1949] The elementary structures of kinship. London: Eyre and Spottiswoode

Lévi-Strauss C 1984 Clan, lignée, maison. C Lévi-Strauss: Paroles données, pp 187241. Paris: PLON.

Loizos P 1975 The Greek gift: politics in a Cypriot village. New York: St. Martin's Press. 
Heady: Fertility as a process of social exchange

Malinowski B 1922 Argonauts of the western Pacific. London: Routledge \& Kegan Paul.

Malinowski B 1929 The sexual life of savages in northwestern Melanesia. London: Routledge \& Kegan Paul.

Mauss M 1990 [1924] The gift: the form and reason for exchange in archaic societies. New York: Norton.

Micheli G 1990 Kinship, family and social network: the anthropological embedment of fertility change in southern Europe. Demographic Research vol. 3, article 13. www.demographic-research.org/Volumes/Vol3/13

Mitterauer M 2003 European kinship systems and household structures. In H.Grandits, P.Heady (eds) Distinct inheritances: property, family and community in a changing Europe pp35-51. Münster: LIT.

Morgan L 1999 [1870] Systems of consanguinity and affinity of the human family (with an introduction by E. Tooker). Lincoln Nebraska (and London UK): University of Nebraska Press.

Murdock G 1949 Social Structure. New York: Free Press.

Netting R 1981 Balancing on an Alp: ecological change and continuity in a Swiss mountain community. Cambridge: CUP.

Parry J, Bloch M 1989 Introduction: money and the morality of exchange. In J Parry, M Bloch (eds) Money and the morality of exchange, pp 1-32. Cambridge: CUP.

Piña D, Bengtson V 1993 The division of labour and wives' happiness: ideology, employment and perceptions of support. Journal of Marriage and the Family 55(4): 901-912.

Reher D 1998 Family ties in western Europe: persistent contrasts. Population and Development Review 24: 203-234.

Segalen M 1991 Fifteen generations of Bretons. Kinship and society in lower Brittany, 1720-1980. Cambridge: CUP.

Segalen M 2003 Kinship ties in European Families. In D.Kertzer, M.Barbagli (eds) History of the European family, Volume 3: Family life in the twentieth century pp 350-376. New Haven: Yale University Press.

Smith E 2003 Human cooperation: perspectives from behavioural ecology. In P Hammerstein (ed) Genetic and cultural evolution of cooperation, pp 401-428. Cambridge Mass: The MIT Press. 
Solinas P, Grilli S 2002 Spazi di alleanza: aree di matrimonialità nella Toscana meridionale. Roma: CISU.

Strathern M 1988 The gender of the gift. Berkeley and Los Angeles: University of California Press.

Surkyn J, Lesthaeghe R 2004 Value orientations and the second demographic transition (SDT) in northern, western and southern Europe: an update. Demographic Research: Special Collection 3, Article 3. www.demographic-research.org

van Gennep A 1981 [1909] Les rites de passage. Paris: Picard.

Viazzo P 1989 Upland communities: environment, population and social structure in the Alps since the sixteenth century. Cambridge: CUP.

Wrigley E 2003 Intrinsic growth rates and inheritance strategies: a perspective from historical demography. In H.Grandits, P.Heady (eds) Distinct inheritances: property, family and community in a changing Europe pp 69-95. Münster: LIT. 
Heady: Fertility as a process of social exchange 